\title{
Reply to a Comment in G. Meinhold "Geochemical Discrimination of Rutile from the Belomorian Mobil Belt"1
}

\author{
S. G. Skublov ${ }^{a, b}$, T. Zack ${ }^{c}$, A. V. Berezin ${ }^{a}$, A. E. Mel'nik ${ }^{a}$, and N. G. Rizvanova ${ }^{a}$ \\ ${ }^{a}$ Institute of Precambrian Geology and Geochronology, Russian Academy of Sciences, \\ nab. Makarova 2, St. Petersburg, 199034 Russia \\ ${ }^{b}$ The National University of Mineral Resources "The University of Mines" \\ 21-st line 2, St. Petersburg, 199106 Russia \\ e-mail:skublov@yandex.ru \\ ${ }^{c}$ Institut für Geowissenschaften, Universität Mainz, \\ Becher Weg 21, Mainz, 55128 Germany \\ e-mail:zack@uni-mainz.de
}

Received July 16, 2013

DOI: $10.1134 / \mathrm{S} 0016702914040090$

The comment of G. Meinhold is concerned with the precise position of the dividing line between the eclogite and metapelite fields on the $\mathrm{Cr}-\mathrm{Nb}$ discrimination diagram for rutile. To date it is a common knowledge that rutiles from metabasic rocks show higher $\mathrm{Cr}$ and lower $\mathrm{Nb}$ concentrations compared with rutiles from metapelitic rocks. It is hardly possible to determine the absolutely precise position of the dividing line between the eclogite and metapelite fields on the diagram for rutiles. The position is to be refined with the extension of the empirical database on rutile geochemistry. In fact the dividing line on the diagram for rutile in [1] is more consistent with the diagram from Meinhold's article [2]. However, the use of the diagram from the later publication of Zack et al. [3] does not change the position of points in the respective fields. Therefore,

\footnotetext{
${ }^{1}$ The article was translated by the authors.
}

a more correct variant of the capture of Fig. 1 in [3] is the following.

Fig. 1. Covariations of (a) $\mathrm{Nb}$ and $\mathrm{Cr}$ and (b) $\mathrm{Nb}$ and $\mathrm{Ta}$ in rutile. (a) The fields of rutile compositions from eclogites and metapelites are after Meinhold [2]; (b) the lines of constant $\mathrm{Nb} / \mathrm{Ta}$ ratios are shown, and analysis 200 of sample 6 is omitted.

\section{REFERENCES}

1. S. G. Skublov, T. Zack, A. V. Berezin, et al., "In situ LA-ICP-MS investigation of the geochemistry and U$\mathrm{Pb}$ age of rutile from the rocks of the Belomorian Mobile Belt," Geochem. Int. 51, 164-171 (2013).

2. G. Meinhold, "Rutile and its applications in Earth sciences," Earth-Sci. Rev. 102, 1-28 (2010).

3. H. Triebold, H. von Eynatten, and T. Zack, "A recipe for the use of rutile in sedimentary provenance analysis," Sediment. Geol. 282, 268-275 (2012). 